\title{
DYNAMICS OF COXIELLA BURNETII DNA IN MILK AND PHASE-SPECIFIC SEROLOGICAL RESPONSE IN DAIRY COWS
}

\author{
Guna Ringa-Karahona ${ }^{1}$, Vita Antane ${ }^{1}$, Lelde Grantina-Ievina ${ }^{2}$, Zanete Steingolde ${ }^{2}$, Julija Trofimova ${ }^{2}$ \\ ${ }^{1}$ Latvia University of Life Sciences and Technologies, Latvia \\ ${ }^{2}$ Institute of Food Safety, Animal Health and Environment BIOR, Latvia \\ guna.ringavet@gmail.com
}

\begin{abstract}
In dairy cows shedding of Coxiella burnetii in milk can be persistent, sporadic to absent. Persistent heavy shedder cows are mostly highly-seropositive. Serological response due to C. burnetii antigenic phase demonstrates acute or chronic infection (serological response to phase II (PhII) or phase I (PhI) antigen, respectively). The aim of this study was to detect dynamics of $C$. burnetii DNA in milk and phase-specific serological response. In this study, the sera samples from 46 animals and milk samples from 34 were collected initially. Milk and sera samples from 36 animals were collected repeatedly. Samples were collected in five herds with previous history of $C$. burnetii infection from different parishes in Latvia - in 2017 and 2018. Milk samples were tested by detection of $C$. burnetii DNA by realtime PCR amplification using 'ADIAVETTM COX REALTIME' (ADIAGENE). Sera were tested by 'VetLine Coxiella Phase1 and Phase2 ELISA' (NOVATEC). Three cows (9\%) in the first sampling and five (14\%) in second sampling demonstrated shedding of $C$. burnetii DNA in milk. Six cows $(13 \%)$ in the first sampling and eight $(22 \%)$ in second sampling demonstrated positive serological response to PhI. Three cows (7\%) in the first sampling and one (3\%) in second sampling demonstrated a questionable serological response to PhI. Two cows (6\%) in the second sampling demonstrated a questionable serological response to PhII . In herds with previous history of $C$. burnetii infection the number of animals demonstrating PhI positve serological response increases significantly $(\mathrm{p}<0.05)$ during six months. In cows demonstrating positive serological response to $\mathrm{PhI}$ it continues and mostly remains unchanged during six months.
\end{abstract}

Key words: Q fever, dairy cows, phase-specific antigen, shedding.

\section{Introduction}

Coxiella burnetii is an ethiological agent of zoonosis Q fever. It is Gram negative bacteria and appears as very short, pleomorphic rod (Babudieri, 1959; Fournier, Marrie, \& Raoult, 1998). The major mechanism whereby $C$. burnetii is transmitted to humans and animals are contaminated aerosols containing bacteria (Angelakis \& Raoult, 2010). C. burnetii are shedded from animals by birth products, vaginal mucus, milk, urine and faeces. No predominant shedding route has been identified (Guatteo et al., 2006) although milk is a significant route of shedding (Guatteo et al., 2007). In dairy cows shedding of $C$. burnetii in milk can be persistent or sporadic to absent. Persistent heavy shedder cows are mostly persistently highly-seropositive (Guatteo et al., 2007). Serology allows to differentiate acute and chronic Q fever infection (Maurin et al., 1999). Due to mutational variation of lipopolysaccharide (LPS) in cell membrane, $C$. burnetii displays two phases of antigen - phase I (PhI) and phase II (PhII). This is similar like rough-smooth variation in family Enterobacteriaceae although chemical structure of LPS from $C$. burnetii is different from those of Gram negative bacteria (Amano \& Williams, 1984; Fournier, Marrie, \& Raoult, 1998; Maurin et al., 1999). PhI antigen is very infectious and corresponds to smooth LPS. When infection occurs, PhI is poorly internalized by monocytes and macrophages and can survive within these cells (Maurin et al., 1999). Due to its cell membrane structure, it can block access of antibodies to its surface (Fournier, Marrie, \& Raoult, 1998). After internalization in host cell C. burnetii can limit proinflammatory response and protect itself from clearance (Sobotta et al., 2016). This is why serological response to $\mathrm{PhI}$ antigen is found only in chronic infections (Angelakis \& Raoult, 2010). PhII antigen is not very infectious, it displays truncated LPS and corresponds to rough LPS. When infection occurs, PhII is easily internalized by monocytes and macrophages and rapidly killed via the phasosomal pathway (Maurin et al., 1999). Q fever in animals is mostly asymptomatic, including a lack of fever (Angelakis \& Raoult, 2010). Because of difficult clinical diagnosis of $\mathrm{Q}$ fever, it can be diagnosed serologically. Antibodies to PhII appear rapidly, reach high titers in 14 days and can persist for 10-12 weeks while antibodies to PhI develop very slowly and presence of them characterises chronic Q fever (Angelakis \& Raoult, 2010; Maurin et al., 1999). Animal classification based on a phase patterns is reasonable (Lucchese et al., 2015). Seroprevalence increases by increasing of animal's age (Böttcher et al., 2011). The aim of this study was to detect dynamics of $C$. burnetii DNA in milk and phase-specific serological response. This study is a continuation of the first study 'Shedding of Coxiella burnetii DNA in milk and antigen phasespecific serological response in dairy herds in Latvia' which has been reported in conference 'Research and Practice in Veterinary Medicine 2017' (Jelgava, Latvia). 


\section{Materials and Methods}

In this study, the sera samples from 46 animals (12 pregnant heifers, 34 milking cows) and milk samples from the same 34 milking cows were collected initially in July and August, 2017. During the time to next sampling 12 pregnant heifers gave birth and became primiparous cows. Also, during this time 10 cows (four primiparous, six multiparous) were culled for different reasons (dystocia with following paresis of hind limbs, lameness, low milk production, ulcer of abomasum etc). No predominant reason of culling was observed. Milk and sera samples from 36 animals were collected repeatedly in February, 2018. Samples were collected in five herds with previous history of $C$. burnetii infection from different parishes in Latvia. As previous history of infection in herd was the evidence of $C$. burnetii DNA in aborted fetuses. Milk samples (approximately $20 \mathrm{~mL}$ ) were collected from all quarters in sterile plastic containers. Tip of teat was cleaned using wipes impregnated with $70 \%$ ethanol. Removing of first milk jet was done before sampling. Blood samples (approximately $5 \mathrm{~mL}$ ) were collected by caudal venipuncture in sterile vacutainers containing a clot activator. Skin was cleaned using wipes impregnated with $70 \%$ ethanol before puncture. Milk and blood samples were chilled until $4{ }^{\circ} \mathrm{C}$ immediately. Milk samples were frozen during $2-6$ hours after sampling. Sera (approximately $1.5 \mathrm{~mL}$ ) were aspirated from blood samples during $24 \mathrm{~h}$ and frozen. Milk and sera samples were stored at $-16{ }^{\circ} \mathrm{C}$ until analysis. Samples collected in July and August 2017 were tested in August and September, 2017. Samples collected in February 2018 were tested in February, 2018. To achieve the correct diagnosis, a combination of different laboratory methods, preferably PCR for the agent detection and ELISA for serology is suggested (Niemczuk et al., 2014). Milk samples were tested by detection of $C$. burnetii DNA by real-time PCR amplification using 'ADIAVETTM COX REALTIME' (ADIAGENE). The method used allows to quantify count of mobile element IS1111 of $C$. burnetii per $1 \mathrm{~mL}$ in milk. Sera were tested by 'VetLine Coxiella Phase1 and Phase2 ELISA' (NOVATEC). The method used allows to detect positive, questionable and negative samples. Data of dynamics of shedding and serological response comparing the first and second sampling were analysed using Z-test (Z Score Calculator for 2 Population Proportions).

\section{Results and Discussion}

In our study, 16 cows demonstrated at least one of parameters detected at least once (Table1). In our study, three cows (9\%) demonstrated shedding of $C$. burnetii DNA in milk initially. One of them demonstrated shedding repeatedly, one was culled before repeated sampling. Three cows were shedders only in the second sampling. In total, five cows (14\%) demonstrated shedding of C. burnetii DNA in milk when tested the second time. There was no significant ( $>0.05$ ) difference in the number of shedders compared the first and second sampling. Shedding in our study was low comparing with other studies where it has been detected from $32 \%$ in 12 herds (Angen et al., 2011) to $50 \%$ in five dairy herds (Guatteo et al., 2007). In our study, six cows (13\%) demonstrated positive serological response to $\mathrm{PhI}\left(\mathrm{PhI}^{+}\right)$initially. Four cows out of $\mathrm{PhI}^{+}$initially demonstrated the same serological response when tested repeatedly (one of them became $\mathrm{PhI}^{+} / \mathrm{PhII}^{+/}$). One $\mathrm{PhI}^{+}$cow was culled before repeated sampling, other one demonstrated no serological response when tested repeatedly. Four cows without serological response initially demonstrated $\mathrm{PhI}^{+}$when tested repeatedly. In total, eight cows (22\%) were $\mathrm{PhI}^{+}$when tested repeatedly. There were significant $(\mathrm{p}<0.05)$ increase of $\mathrm{PhI}^{+}$ cows comparing the first and second sampling. The $\mathrm{PhI}^{+} / \mathrm{PhII}^{-}$pattern as a rare finding was described in seven multiparous cows out of 1932 animals in 105 herds. Subsequently, five of them became negative. In the same study $\mathrm{PhI}^{+} / \mathrm{PhII}^{-}$pattern developed from pattern $\mathrm{PhI}^{+} / \mathrm{PhII}^{+}$in six animals (Böttcher et al., 2011). It is in contradiction with our finding where pattern $\mathrm{PhI}^{+} / \mathrm{PhII}^{+/}$developed from $\mathrm{PhI}^{+}$. However, no shedding of $C$. burnetii DNA in milk in this study was detected. In our study, three cows (9\%) demonstrated a questionable serological response to $\mathrm{PhI}\left(\mathrm{PhI}^{+/-}\right)$initially. One of $\mathrm{PhI}^{+/-}$cows initially had no serological response when tested repeatedly. Other two of them were culled before repeated sampling. One cow (3\%) demonstrated $\mathrm{PhI}^{+/-}$serological response when tested repeatedly. No significant $(\mathrm{p}>0.05)$ increase of $\mathrm{PhI}^{+/}$cows was observed comparing the first and second sampling. Only two cows (6\%) in repeated sampling demonstrated a questionable serological response to $\mathrm{PhII}\left(\mathrm{PhII}^{+/}\right)$. Both of them demonstrated $\mathrm{PhI}^{+} /$ $\mathrm{PhII}^{+/}$serological pattern. To the best of our knowledge, no reports related by questionable phase-specific serological response to $C$. burnetii antigen are available. None of cows demonstrated serological response to PhII initially. This finding is in contradiction with Böttcher et al., 2011 study where serological response to PhII was a frequent finding. In our study, it was one cow shedding $C$. burnetii DNA in milk without any serological response initially. It matches with Barberio et al., 2014 finding where out of 36 cows shedding C. burnetii DNA in milk, 11 had no antibodies in sera detectable by ELISA. Shedding may not be the correct tool, especially if a cow is suffering from new infection (Garcia-Ispierto et al., 2013). 
Dynamics of Coxiella burnetii DNA shedding in milk and phase-specific serological response

\begin{tabular}{|c|c|c|c|}
\hline \multicolumn{2}{|c|}{ First sampling } & \multicolumn{2}{|c|}{ Second sampling } \\
\hline Serological response & Shedding & Serological response & Shedding \\
\hline $\mathrm{PhI}^{+/-}$ & $\mathrm{DNA}^{-}$ & $\mathrm{Ph}^{-}$ & $\mathrm{DNA}^{-}$ \\
\hline $\mathrm{Ph}^{-}$ & $\mathrm{DNA}^{-}$ & $\mathrm{PhI}^{+}$ & $\mathrm{DNA}^{+}$ \\
\hline $\mathrm{Ph}^{-}$ & $\mathrm{DNA}^{-}$ & $\mathrm{PhI}^{+} / \mathrm{PhII}^{+/-}$ & $\mathrm{DNA}^{-}$ \\
\hline $\mathrm{Ph}^{-}$ & $\mathrm{DNA}^{-}$ & $\mathrm{Ph}^{-}$ & $\mathrm{DNA}^{+}$ \\
\hline $\mathrm{Ph}^{-}$ & $\mathrm{DNA}^{-}$ & $\mathrm{Ph}^{-}$ & $\mathrm{DNA}^{+}$ \\
\hline $\mathrm{PhI}^{+/-}$ & $\mathrm{DNA}^{+}$ & \multicolumn{2}{|c|}{ animal culled } \\
\hline $\mathrm{Ph}^{-}$ & $\mathrm{DNA}^{-}$ & $\mathrm{PhI}^{+}$ & $\mathrm{DNA}^{-}$ \\
\hline $\mathrm{PhI}^{+}$ & $\mathrm{DNA}^{+}$ & $\mathrm{PhI}^{+} / \mathrm{PhII}^{+/-}$ & $\mathrm{DNA}^{-}$ \\
\hline $\mathrm{Ph}^{-}$ & $\mathrm{DNA}^{+}$ & $\mathrm{PhI}^{+/-}$ & $\mathrm{DNA}^{+}$ \\
\hline $\mathrm{PhI}^{+}$ & $\mathrm{DNA}^{-}$ & $\mathrm{PhI}^{+}$ & $\mathrm{DNA}^{-}$ \\
\hline $\mathrm{PhI}^{+}$ & $\mathrm{DNA}^{-}$ & $\mathrm{PhI}^{+}$ & $\mathrm{DNA}^{-}$ \\
\hline $\mathrm{Ph}^{-}$ & $\mathrm{DNA}^{-}$ & $\mathrm{PhI}^{+}$ & $\mathrm{DNA}^{+}$ \\
\hline $\mathrm{PhI}^{+}$ & $\mathrm{DNA}^{-}$ & \multicolumn{2}{|c|}{ animal culled } \\
\hline $\mathrm{PhI}^{+}$ & $\mathrm{DNA}^{-}$ & $\mathrm{PhI}^{+}$ & $\mathrm{DNA}^{-}$ \\
\hline $\mathrm{PhI}^{+}$ & $\mathrm{DNA}^{-}$ & $\mathrm{Ph}^{-}$ & DNA $^{-}$ \\
\hline $\mathrm{PhI}^{+/-}$ & $\mathrm{DNA}^{-}$ & \multicolumn{2}{|c|}{ animal culled } \\
\hline
\end{tabular}

$\mathrm{DNA}^{+}$- shedding of $C$. burnetii in milk, DNA ${ }^{-}$- non shedding of $C$. burnetii in milk, $\mathrm{PhI}^{+}-$positive serological response to C. burnetii Phase I antigen, $\mathrm{PhI}^{+/-}$- questionable serological response to $C$. burnetii $\mathrm{Phase} \mathrm{I}$ antigen, $\mathrm{PhII}^{+/}$- questionable serological response to $C$. burnetii $\mathrm{PhII}$ antigen, $\mathrm{Ph}^{-}-$no serological response to any of $C$. burnetii phase antigen.

\section{Conclusions}

The study demonstrated that $\mathrm{PhI}^{+/}$serological response without shedding of $C$. burnetii in milk can evanish completely. In cow shedding of $C$. burnetii DNA in milk, serological response to PhI appears during six months. Cows without phase-specific serological response or shedding become shedders with or without serological response to Ph during six months. In herds with previous history of $C$. burnetii infection, the number of shedders or animals with serological response increases over time. The number of animals with $\mathrm{PhI}^{+}$serological response increases significantly $(\mathrm{p}<0.05)$. It indicates that infection is active in the herd level. Pattern of serological response $\mathrm{PhI}^{+}$which is characteristic to chronic infection mostly stays unchanged during six months or can change to $\mathrm{PhI}^{+} / \mathrm{PhII}^{+/}$. There are difficulties to permit definitive conclusions due to $21 \%$ of animals that were culled before repeated sampling. The study will be continued.

\section{Acknowledgements}

The present study was supported financially by the Scientific Committee of Latvia University of Life Sciences and Technologies (research project „Prevalence of Q fever in dairy herds in Latvia and its effect to reproduction parameters", project No.A0502) within the framework of the research project "Strengthening Scientific Capacity of LLU”. The authors appreciate laboratory work done by Artjoms Malisevs as well as are grateful to Dr.med.vet. Ilga Sematovica (Jelgava, Latvia) and Dr.med.vet. Laura Mancevica (Jelgava, Latvia) for critical reading of the manuscript.

\section{References}

1. Amano, K.I., \& Williams, J.C. (1984). Chemical and immunological characterization of lipopolysaccharides from phase I and phase II Coxiella burnetii. Journal of Bacteriology, 160(3), 994-1002.

2. Angelakis, E., \& Raoult, D. (2010). Q fever. Veterinary Microbiology, 140, 297-309. DOI: 10.1016/j. vetmic.2009.07.016.

3. Angen, Ø., Ståhl, M., Agerholm, J.S., Christoffersen, A.-B., \& Agger, J.F. (2011). Dynamics of relationship between the presence of Coxiella burnetii DNA, antibodies, and intrinsic variables in cow milk and bulk tank milk from Danish dairy cattle. Journal of Dairy Science, 94(12), 5759. DOI: 10.3168/jds.2011-4197.

4. Babudieri, B. (1959). Q Fever: A Zoonosis. Adv. Vet. Sci., 5, 82-182. 
5. Barberio, A., Badan, M., Busa, A., Ceglie, L., Capello, K., Comin, A., \& Natale, A. (2014). Association between serological response and shedding of Coxiella burnetii in milk in dairy cattle. Large Animal Review, 20(1), 3-8.

6. Böttcher, J., Vossen, A., Janowetz, B., Alex, M., Gangl, A., Randt, A., \& Meier, N. (2011). Insights into the dynamics of endemic Coxiella burnetii infection in cattle by application of phase-specific ELISAs in an infected dairy herd. Veterinary Microbiology, 151(3-4), 291-300. DOI: 10.1016/j.vetmic.2011.03.007.

7. Fournier, P.E., Marrie, T.J., \& Raoult, D. (1998). Diagnosis of Q fever. Journal of Clinical Microbiology, 36(7), 1823-1834. DOI: 0095-1137/98/\$04.00?0.

8. Garcia-Ispierto, I., Lopez-Helguera, I., Tutusaus, J., Serrano, B., Monleon, E., Badiola, J., \& Lopez-Gatius, F. (2013). Coxiella burnetii Shedding During the Peripartum Period and Subsequent Fertility in Dairy Cattle. Reproduction in Domestic Animals, 446, 441-446. DOI: 10.1111/rda.12095.

9. Guatteo, R., Beaudeau, F., Berri, M., Rodolakis, A., Jolyc, A., \& Seegers, H. (2006). Shedding routes of Coxiella burnetii in dairy cows: Implications for detection and control. Veterinary Research, 37(6), 827-833. DOI: 10.1051/vetres:2006038.

10. Guatteo, R., Beaudeau, F., Joly, A., \& Seegers, H. (2007). Coxiella burnetii shedding by dairy cows: Original article. Vet.Res., 38, 849-860.

11. Lucchese, L., Capello, K., Barberio, A., Zuliani, F., Stegeman, A., Ceglie, L., ... Natale, A. (2015). IFAT and ELISA phase I/phase II as tools for the identification of Q fever chronic milk shedders in cattle. Veterinary Microbiology, 179(1-2), 102-108. DOI: 10.1016/j.vetmic.2015.02.010.

12. Maurin, M., Raoult, D., Location, I., \& Cycle, I. (1999). Q Fever. Clinical Microbiology Reviews, 12(4), 518-553.

13. Niemczuk, K., Szymańska-Czerwińska, M., Śmietanka, K., \& Bocian, Ł. (2014). Comparison of diagnostic potential of serological, molecular and cell culture methods for detection of Q fever in ruminants. Veterinary Microbiology, 171(1-2), 147-152. DOI: 10.1016/j.vetmic.2014.03.015.

14. Sobotta, K., Hillarius, K., Mager, M., Kerner, K., Heydel, C., \& Menge, C. (2016). Coxiella burnetii infects primary bovine macrophages and limits their host cell response. Infection and Immunity, 84(6), 1722-1734. DOI: 10.1128/IAI.01208-15. 